\title{
Djáknar á Íslandi í 25 ár
}

\author{
Skýrsla
}

\section{Inngangur}

Pessi skýrsla um stöðu djákna í íslensku pjóðkirkjunni á árunum 1995-2019 var unnin af Halldóri Elíasi Guðmundssyni í samstarfi við Ragnheiði Sverrisdóttur fyrir kærleikspjónustusvið Biskupsstofu. Markmiðið með henni er að lýsa próun á stöðu djákna og kasta fram spurningum um framtíðarhlutverk djákna í íslensku pjóðkirkjunni.

\section{Aðferðafræði}

Um mitt ár 2019 leitaði kærleikspjónustusvið Biskupsstofu til skýrsluhöfundar og óskaði eftir samantekt á upplýsingum um próun djáknaembættisins í íslensku pjóðkirkjunni frá árinu 1995, en pað ár brautskráðust fyrstu djáknakandídatarnir frá Háskóla Íslands.

Degar pessi vinna hófst kom fljótlega í ljós að ekki var hægt að finna á einum stað upplýsingar um nám, vígslu, starfspjálfun og starfsvettvang djákna. Kærleikspjónustusvið Biskupsstofu hafði undir höndum nokkra nafnalista yfir djákna og djáknakandídata. Pessir listar höfou verið útbúnir á mismunandi tímum og á peim var stundum tiltekinn starfsvettvangur skráður og upplýsingar um starfspjálfun. Höfundur sameinaði listana í einn og var sá listi síðan notaður sem grunnur að frekari gagnasöfnun. Við gagnasöfnunina var notast við fréttatilkynningar á vefsíðu kirkjunnar og í fjölmiðlum, ásamt starfsauglýsingum. Stuðst var við Árbakur kirkjunnar, jafnt skýrslur prófasta í peim sem lista yfir starfsfólk. Degar misræmi fannst, eða ef ekki tókst að finna upplýsingar um einstaka djákna, var leitað eftir upplýsingum á heimasíðum safnaða og í einhverjum tilfellum var stuðst við óskráð og óformleg samtöl. Đá var notast við tilkynningar Háskóla Íslands um brautskráningar frá skólanum til að fá upplýsingar um fjölda brautskráðra djáknakandídata við hverja brautskráningu frá febrúar 1995 og fram til hausts 2019.

Gögnunum var safnað í gagnagrunn par sem teknar voru saman upplýsingar um fæðingardag, kyn, útskrift úr starfspjálfun, vígsludag, vígslunúmer, menntun og kirkjulegan starfsvettvang vígðra djákna. Grunnurinn er nú í vörslu Biskupsstofu.

\section{Yfirlit}

Frá pví að fyrsti djákninn í íslensku pjóðkirkjunni var vígður á síðari tímum og fram í september 2019 hafa 62 djáknar starfað í trúarlegri pjónustu á Íslandi. Af peim voru 
prjú vígð á Íslandi fyrir árið $1995^{1}$ og tvö erlendis², sem síðar komu til pjónustu í íslensku pjóðkirkjunni. Alls hafa 57 einstaklingar pegið djáknavígslu á Íslandi frá árinu 1995 og hafa flestar peirra farið fram í Dómkirkjunni í Reykjavík en nokkrar í Skálholtsdómkirkju. Í heildina má pví líta svo á að 62 djáknar hafi starfað á Íslandi nú í seinni tíð, p.e. á tímabilinu sem skýrslan tekur til og á árunum par á undan.

\section{Upplýsingar um nám}

Af peim 57 sem hafa pegið djáknavígslu á Íslandi frá 1995 sést að tvö luku námi erlendis en 55 við Háskóla Íslands. Á ofangreindu tímabili lauk alls 121 djáknanámi frá Háskóla Íslands og af peim luku 110 starfspjálfun í pjóðkirkjunni.

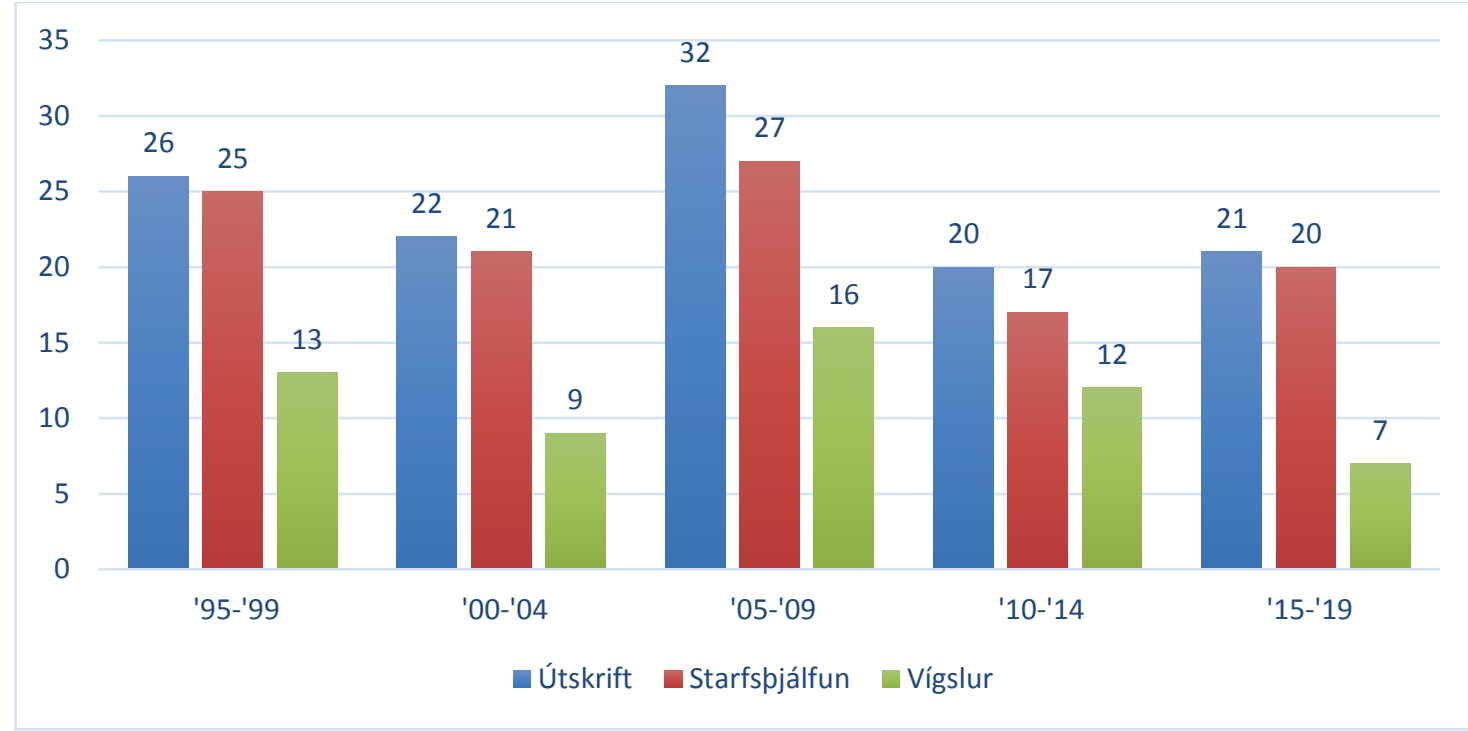

Mynd 1. Yfirlit yfir fjölda peirra sem luku djáknanámi frá Háskóla Íslands á ofangreindum tímabilum, peirra sem luku starfspjálfun í pjóðkirkjunni og peirra sem páðu djáknavígslu.

Á pví 25 ára tímabili sem hér er til umfjöllunar, p.e. frá 1995-2019, hlutu 50\% peirra sem luku starfspjálfun hjá pjóðkirkjunni vígslu. Hæst varð hlutfallið á árunum 2010_ 2014 pegar tæplega 71\% af brautskráðum nemum úr starfspjálfun hlaut vígslu. Lægst var hlutfallið aftur á móti á tímabilinu 2015-2019 pegar hlutfall vígðra var 35\% af peim sem luku starfspjálfun.

Athygli vekur að pau sem hafa pegið vígslu sem djáknar voru allflest vígð innan tveggja ára frá lokum starfspjálfunar, eða 35 af 55. ${ }^{4}$ Ellefu til viðbótar fengu vígslu innan fjögurra ára og sex eftir fjögur til sjö ár. Tveir djáknar voru vígðir eftir lengri bið, önnur fékk vígslu sjö og hálfu ári eftir starfspjálfun og hin fjórtán og hálfu ári eftir að starfspjálfun lauk.

एá er eftirtektarvert að 28 hafa verið vígð af peim 46 sem lokið hafa BA-gráðu í guðfræði — djáknanámi, eða tæplega 61\%, en aftur á móti einungis 36\% peirra sem lokið hafa 60e framhaldsnámi, svokallaðri viðbótardiplómu (27 af 75). Pegar skoðuð

\footnotetext{
${ }^{1}$ Vígsla til pjónustu í Grímsey 1961, vígsla til pjónustu í Hallgrímskirkju 1965 og vígsla til pjónustu í Grensáskirkju 1979.

2 Vígsla í Sví́pjóð 1981 og vígsla í Pýskalandi 1997.

${ }^{3}$ Nám í Danmörku (vígsla árið 2000) og nám í Noregi (vígsla 2002).

4 Í pessari tölu eru ekki pau sem páðu vígslu fyrir 1995 eða voru vígð eða lærðu erlendis.
} 
er samsetning peirra sem lokið hafa viðbótardiplómu og fengið vígslu má sjá að prettán höfðu áður lokið kennaranámi, tvær voru leikskólakennarar og átta höfðu lokið námi í hjúkrunarfræði. Pá höfðu fjórar lokið annars konar háskólanámi.

Rétt er að nefna að af sjö körlum sem lokið hafa starfspjálfun sem djáknar á Íslandi frá 1995 hafa fimm pegið djáknavígslu, eða 71\%, en 50 af 103 konum, eða 48,5\%.

\section{Hverjir eru djáknar?}

Hlutfall kvenna af djáknum er 85\%, eða 53 af 62. Kynjahlutfall peirra sem lokið hafa starfspjálfun á Íslandi er aftur á móti pannig að konur eru 94\% peirra sem lokið hafa starfspjálfun, eða 103 af 110, og karlar pá 6\%. Meðalaldur djákna við vígslu er 44 ár og sjö mánuðir. Meðalaldur karlanna við vígslu er 36 ár og prír mánuðir en meðalaldur kvennanna er 46 ár. Sex djáknar hafa fengið vígslu fyrir prítugt en fjögur eftir sextugt.

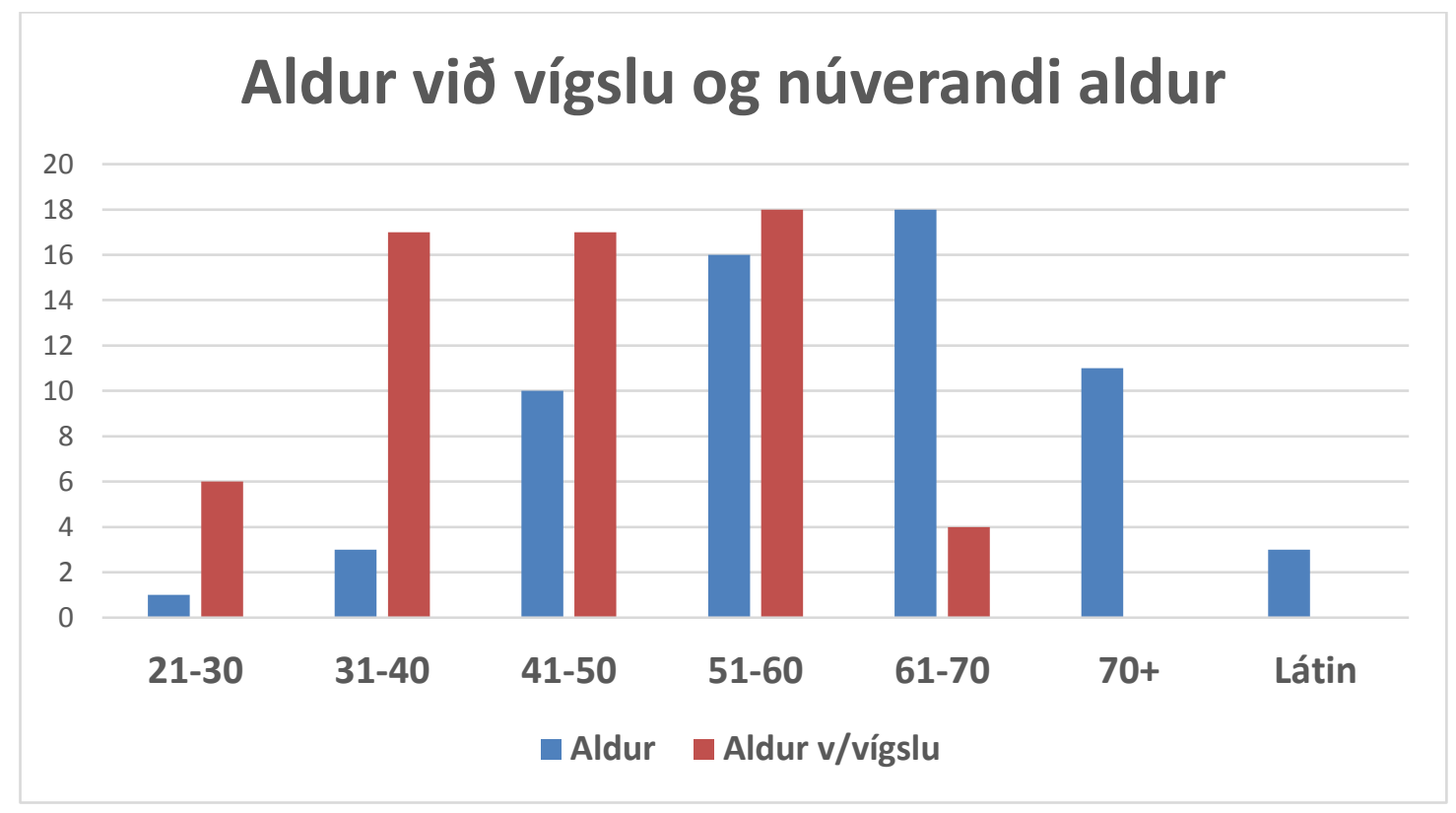

Mynd 2. Fjöldi djákna sem var á tilteknum aldri í lok september (pegar upplýsingum var safnað) (blá súla) og fjöldi djákna sem var á tilteknum aldri við vígslu (rauð súla).

Degar upplýsingarnar um djáknahópinn voru teknar saman í september 2019 má jafnframt sjá að einungis fjögur eru undir fertugu, átján djáknar eru yfir sextugu, ellefu eru yfir sjötugu og prjú eru látin.

\section{Störf djákna}

Mikilvægt er að taka fram að upplýsingar um fjölda djákna 1 störfum hjá kirkjunni eru nokkuð á reiki. Ekki er til samræmdur skilningur á pví hvað felst í að vera djákni í trúarlegri pjónustu. Sú leið er farin í pessari skýrslu að miða eingöngu við pá djákna ráðnir eru til að sinna trúarlegri pjónustu við kirkjur eða hjá félagasamtökum og stofnunum sem veita slíka pjónustu. 
prátt fyrir að 62 einstaklingar hafi pjónað sem djáknar á Íslandi á tímabilinu sem skýrslan tekur til hafa aldrei fleiri en 28 verið í trúarlegri pjónustu hjá kirkjunni, stofnunum eða félagasamtökum á sama ári, en pað gerðist árin 2007 og 2008. Frá árinu 1995 og til ársins 2007 mátti sjá djáknum í trúarlegri pjónustu fjölga jafnt og pétt en frá 2008 hefur djáknum í trúarlegri pjónustu aftur á móti fækkað. Fjöldinn náði lágmarki 2013 annars vegar og 2018 hins vegar. Pau ár voru einungis 19 djáknar í trúarlegri pjónustu og höfðu djáknar ekki verið svo fáir frá árinu 2001. Síðan fjölgaði peim aftur á árinu 2019 en pað ár voru peir 22.

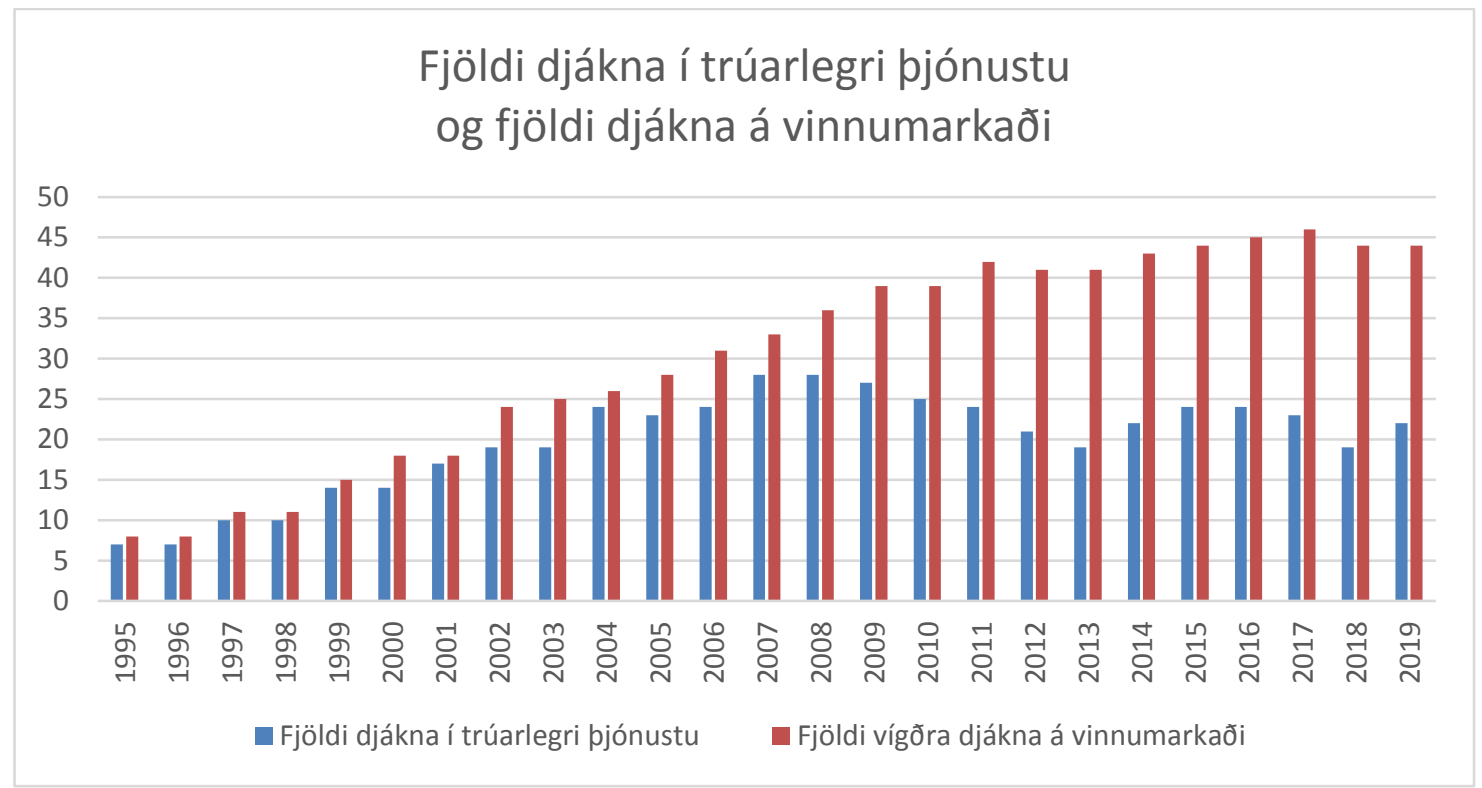

Mynd 3. Fjöldi djákna í trúarlegri pjónustu (b.e. hjá pjóðkirkjunni, stofnunum (t.d. sjúkrastofnunum) og félagasamtökum) annars vegar og fjöldi djákna alls á vinnumarkaði hins vegar (p.e. bæði við trúarlega pjónustu og utan hennar).

Djáknum alls á vinnumarkaði (p.e. bæði í og utan trúarlegrar pjónustu) fjölgaði mjög hratt frá 1995 og fram til 2011 pegar djáknar voru alls 42. ${ }^{5}$ Frá 2011 hafa djáknar alls á vinnumarkaði verið á milli 41 og 46.

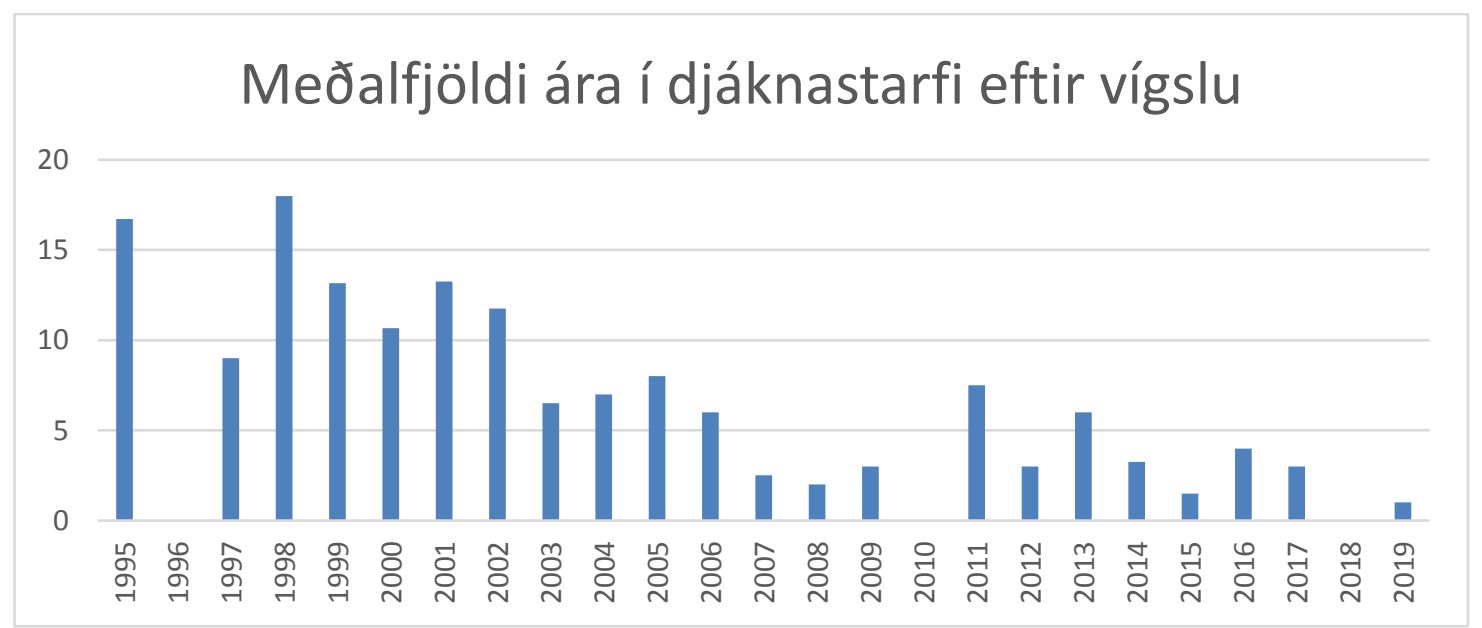

Mynd 4. Starfsreynsla djákna við trúarlega pjónustu í árum talið að meðaltali árið 2019 (lóðrétti ásinn) eftir vígsluári (lárétti ásinn).

${ }_{5}^{5}$ Djáknar eldri en 70 ára teljast ekki virkir á vinnumarkaði. Eins eru djáknar sem hafa tekið prestsvígslu ekki hafðir með í pessum tölum. 
Degar meta á hversu langan starfsaldur djáknar hafa í trúarlegri pjónustu má gefa sér að pau sem hafa hæstan vígslualdur hafi að öðru jöfnu einnig lengstan starfsaldur. Pegar starfs-/vígslualdur er settur upp í stöplarit ætti að fást tiltölulega einföld yfirsýn (mynd 4). Súlan lengst til vinstri ætti að vera hæst en síðan ættu súlurnar að lækka jafnt og pétt eftir pví sem að við færumst nær árinu 2019. Degar meðalstarfsaldur, miðað við vígsluár, er skoðaður kemur hins vegar í ljós að stöplaritið er ekki eins og reikna hefði mátt með. Djáknar sem voru vígðir á árunum 2003-2010 hafa starfað mun skemur sem djáknar en pau sem voru vígð á árunum bæði á undan og eftir. petta frávik í starfsaldri er vert nánari skoðunar. Đó að efnahagshrunið komi upp í hugann sem skýring, má velta fyrir sér hvort sú skýring sé einhlít eða hvort aðrar ástæður kunni að liggja hér að baki.

Eins og áður hefur komið fram hafa djáknanemar mismunandi bakgrunn, auk pess sem tvær ólíkar námsleiðir eru í boði. Degar skoðaður er fjöldi ára í trúarlegri pjónustu með hliðsjón af fyrri menntun og pví hvor námsleiðanna hefur verið valin vekur athygli að hjúkrunarfræðingar með viðbótardiplómu höfðu árið 2019 verið í trúarlegri pjónustu sem djáknar að jafnaði i 13 ár en djáknar með BA-próf í rétt um 6,5 ár.

Nánari greiningu á pessu má sjá á mynd 5 hér á eftir.

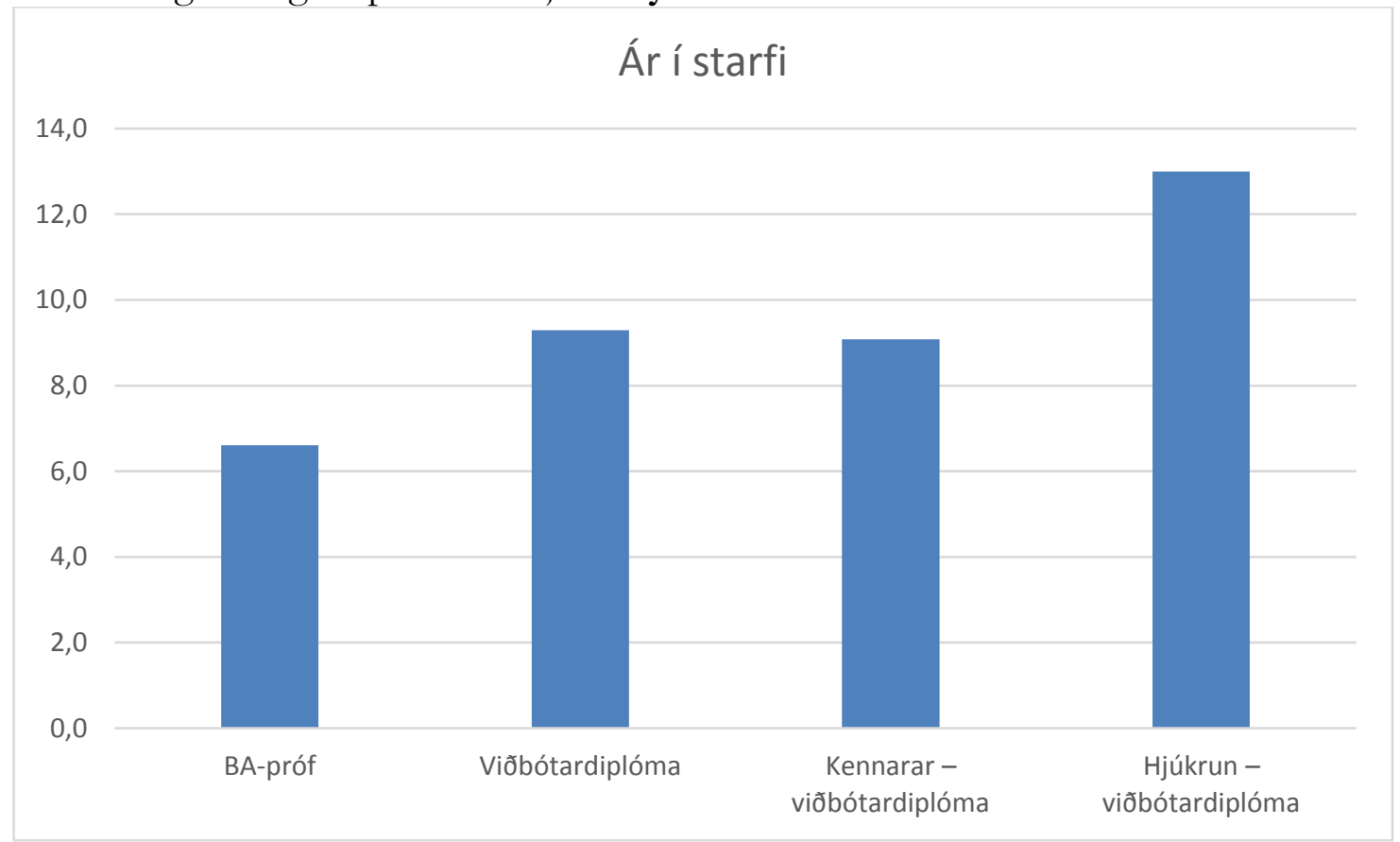

Mynd 5. Meðalstarfsaldur djákna við trúarlega pjónustu að meðaltali, skipt eftir námsleið og fyrra námi.

\section{Hverjir ráða djákna?}

Frá árinu 1995 hafa 59 vinnuveitendur ráðið djákna til trúarlegrar pjónustu. Af peim eru 29 söfnuðir og fimm kirkjustofnanir eða prófastsdæmi, 16 sjúkrastofnanir eða hjúkrunarheimili, fjórir skólar og fimm félagasamtök. Í nokkrum tilfellum er um samstarfsverkefni að ræða milli tveggja eða fleiri vinnuveitenda.

Af pessum 29 söfnuðum eru 16 í Reykjavíkurprófastsdæmunum og sex í Kjalarnesprófastsdæmi. Pá hafa prír söfnuðir í Suðurprófastsdæmi haft djákna í starfi, tveir 
söfnuðir í Eyjafjarðar- og Pingeyjarprófastsdæmi og auk pess starfaði djákni um tíma í sameiginlegu verkefni tveggja prestakalla í Vesturlandsprófastsdæmi. Einn djákni var vígður til safnaðar utan pjóðkirkjunnar.

Degar vinnustaðirnir eru skoðaðir nánar kemur í ljós að 37 af pessum vinnustöðum hafa haft djákna í vinnu skemur en tíu ár. Jafnframt hafa 37 vinnustaðir einvörðungu haft einn djákna í vinnu frá 1995, pótt ekki séu pað sömu vinnustaðir.

Við getum séð að 22 vinnuveitendur hafa haft djákna í starfi í tíu ár eða lengur. Fjórtán peirra hafa haft fleiri en einn djákna í starfi á pessum árum. Par af eru tíu söfnuðir, einn skóli, ein félagasamtök, Hjúkrunarheimilið Sóltún og Biskupsstofa. Færa má rök fyrir pví að hjá pessum fjórtán vinnuveitendum sé til staðar skilningur á djáknapjónustu sem hefur leitt til langtímaráoningarsambands við fleiri en einn djákna, enda er pað svo að af pessum fjórtán vinnuveitendum eru einungis prír sem ekki hafa starfandi djákna í dag. Peir eru Öryrkjabandalag Íslands, sem var í samstarfi við Laugarneskirkju (ein staða, tveir vinnuveitendur) en par er nú safnaðarráðinn prestur, og priðji vinnuveitandinn er Selfosskirkja, en par var bætt við stöðu prests um pað leyti sem djáknastaðan var lögð niður.

pannig má færa rök fyrir pví að ellefu vinnuveitendur leggi ríka áherslu á að ráða djákna til trúarlegrar pjónustu. Um er að ræða tíu stöður, par sem í einu tilfelli er um samstarfsverkefni tveggja vinnuveitenda að ræða (Lágafellssóknar og Lágafellsskóla).

\section{Ráðningar djákna}

Eins og áður hefur komið fram pá hefur tæplega 61\% peirra djáknakandídata sem lokið hafa BA-gráðu ${ }^{6}$ fengið vígslu en einungis $36 \%$ peirra sem lokið hafa viðbótardiplómu. ${ }^{7}$

Átta einstaklingar sem bætt hafa við sig diplópanámi eftir hjúkrunarnám hafa pegið vígslu. Af peim voru fjórar vígðar fyrir aldamót og einn hjúkrunarfræðingur hefur fengið vígslu síðan 2008. Í sjö tilvikum af átta par sem hjúkrunarfræðingur var vígður til starfa sem djákni hjá tilteknum vinnuveitanda var sú hin sama pegar í vinnu hjá sama vinnuveitanda fyrir vígsluna og/eða tók virkan pátt í að koma djáknastöðunni á fót.

Um djákna sem hafa lokið viðbótardiplómu eftir kennaranám er mjög svipaða sögu að segja. Af prettán kennurum með viðbótardiplómu voru a.m.k. níu pegar í vinnu hjá sama vinnuveitanda fyrir djáknavígsluna og eftir hana.

Í starfsreglum pjóðkirkjunnar um djákna nr. 738/1998, með síðari breytingum, kemur fram að

Biskup Íslands auglýsi[r] laus störf djákna í samráði við vinnuveitanda. Biskup kannar hvort umsækjendur uppfylli lögboðin skilyrði til starfsins. Að liðnum umsóknarfresti sendir biskup umsóknir ásamt umsögn sinni til hlutaðeigandi vinnuveitanda (sóknarnefndar, stofnunar eða líknarfélags), sem ákveður, að höfðu lögboðnu samráði, hver skuli ráðinn og tilkynnir pað prófasti.

Eins og fram kemur hér að ofan hefur biskup ekki fylgt starfsreglum og auglýst starf djákna í að minnsta kosti 17 af peim 21 skipti pegar ráðinn hefur verið djákni með kennara- eða húkrunarmenntun. 
Hvað varðar djákna með BA-próf er staðan örlítið önnur. Glerárkirkja, Áskirkja, Bessastaðasókn, Fella- og Hólakirkja og Hjúkrunarheimilið Sóltún eru einu vinnuveitendurnir sem hafa oftar en einu sinni fengið biskup Íslands til að auglýsa djáknastarf. Í einhverjum tilvikum hafa söfnuðir auk pess fengið biskup til að auglýsa slíkt starf sem pegar hefur verið gengið frá ráðningu í, til að uppfylla skilyrði starfsreglnanna.

Pá er algengt að félagasamtök og söfnuðir auglýsi eftir starfsfólki til að sinna einstökum starfspáttum í starfi sínu og sé djákni ráđinn í starfið hafa vinnuveitendur að öðru jöfnu talað um að hafa „djákna í starfi“, prátt fyrir að biskup Íslands hafi ekki auglýst starfið og sent umsögn til vinnuveitanda, líkt og gert er ráð fyrir í starfsreglunum.

Dví virðist að pað gerist sjaldnar en hitt að stuðst sé við starfsreglur um djákna pegar kemur að ráðningum djákna eða djáknakandídata. Hér er pó vert að nefna að á árunum 2013 og 2014 auglýsti biskup sex djáknastörf en svo mörg djáknastörf hafa ekki verið auglýst á tveggja ára tímabili, hvorki fyrr né síðar.

\section{Staða djákna}

Á haustdögum 2019 starfaði 21 djákni við trúarlega pjónustu. Af peim höfðu tveir tvo vinnuveitendur. Djáknar störfuðu í prettán söfnuðum, fjögur hjá sjúkra- og hjúkrunarstofnunum, tvö hjá félagasamtökum, tvö á Biskupsstofu, ein við prófastsdæmi og ein í skóla, alls gera petta 23 vinnuveitendur.

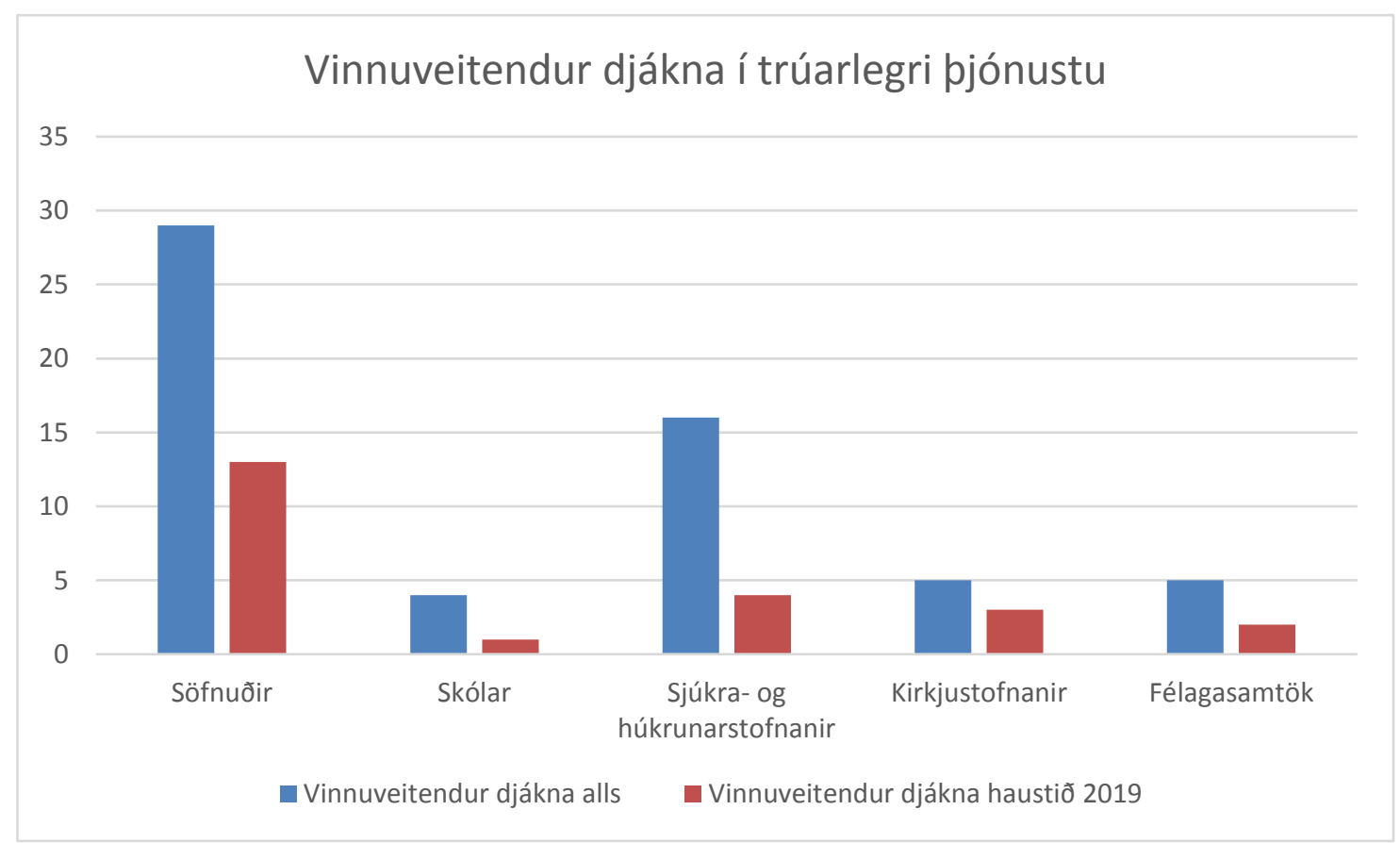

Mynd 6. Heildarfjöldi vinnuveitenda sem hafa haft djákna í trúarlegri pjónustu annars vegar og vinnuveitendur sem höfou djákna í trúarlegri pjónustu í september 2019 hins vegar. 
Pegar horft er til pess að 59 vinnuveitendur hafa haft djákna í trúarlegri pjónustu, pá blasir við að sextán söfnuðir og ellefu sjúkra- og hjúkrunarstofnanir, prenn félagasamtök, prír skólar og tvær kirkjustofnanir sem hafa haft djákna í starfi hafa ekki lengur slíkan starfsmann. Баð er mikilvægt að velta fyrir sér hvort mismunandi hugmyndir um starfssvið, stöðu og hlutverk djákna hafi átt pátt í að skapa pær aðstæður að 60\% peirra vinnuveitenda sem hafa haft djákna í starfi hjá sér hafa ekki lengur slíka starfsmenn.

\section{Fjölpætt köllun og hlutastörf}

Frá pví að djáknavígslur voru teknar upp að nýju undir lok tuttugustu aldar hafa störf djákna oftar en ekki verið í formi hlutastarfa. Ekki reyndist unnt að fá upplýsingar um starfshlutfall einstakra djákna síðustu 25 ár svo að upplýsingar eru pví miður ekki tiltækar um starfshlutföll. Pess eru dæmi um að djáknar séu ráðnir í 100\% starf í söfnuðum og á stofnunum par sem hluti starfsins er skilgreindur sem djáknastarf og annar hluti pess skilgreindur á annan hátt, t.d. sem kirkjuvarsla, skrifstofupjónusta, mannauðsstjórnun eða hjúkrun. Á árinu 2019 voru um 40\% starfandi djákna í fullu starfi sem djáknar en aðrir ýmist í hlutastörfum eða í fullu starfi par sem hluti starfsins var skilgreindur sem ,„,ekki“ djáknastarf“.

\section{Vígsluskilningur í pjóðkirkjunni}

Mikilvægt er að skoða embættis- og vígsluskilning í íslensku pjóðkirkjunni til að skilja til fulls merkingu, stöðu og hlutverk djákna og framtíð djáknapjónustunnar. Vísbendingar eru um að djáknavígsla og hlutverk hennar séu túlkuð á mismunandi hátt eftir hverjum og einum. Ýmsir túlki vígsluna sem eign eða starfsréttindi vígslupega en ekki sem hlutverk eða pjónustu sem vígslupegi sinnir ásamt kirkjunni sem heild, söfnuði eða sókn. Sambærilegan skilning á vígslu má sjá hjá ýmsum prestum pjóðkirkjunnar. Dessi vandi verður enn ljósari hjá djáknum pegar starfsreglum kirkjunnar er ekki fylgt við ráðningar. Hjá djáknum sem starfa við stofnanir eða í félagasamtökum, án vel skilgreindra tengsla við kirkjuna í heild eða einstaka söfnuði, styrkist pessi einstaklingsbundni vígsluskilningur og раð аð vera djákni verður fyrst og fremst starfstitill eða sérfræðiheiti.

petta parf að bæta með pví að tengja djákna á stofnunum og í félagasamtökum við kirkjuna með skýrum hætti, t.d. í gegnum sóknarkirkjur eða prófasta og/eða með skýrri upplýsingaskyldu djákna um störf sín gagnvart biskupi. Hér er brýnt að finna leiðir til að virkja tilsjónarhlutverk biskups og/eða prófasts með pjónustu djákna. Við pað mætti hafa til hliðsjónar hvernig staðið er að eftirliti með störfum sérpjónustupresta.

\section{Nýsköpun í tómarúmi}

Djáknar hafa áhugaverðan starfsvettvang í söfnuðum, félagasamtökum og stofnunum, par sem hlutverk peirra er m.a. að skapa nýjar leiðir í trúarlegri pjónustu. Nýsköpun og frampróun kalla eftir grunni sem hægt er að byggja petta starf á. Deir djáknar sem hafa komið til pjónustu eftir starfsferil sem hjúkrunarfræðingar eða 
kennarar, hafa mörg getað nýtt fyrri reynslu til að byggja upp fjölbreytt og áhugavert starf á mótum fyrri starfsferils og guðfræði. Fyrir nývígðan djákna getur verið mjög erfitt að ná árangri á nýjum starfsvettvangi án fyrri reynslu af kirkjulegu starfi, án starfsreynslu í kennslu eða húkrun eða ef fyrir í söfnuðinum/starfinu er ekki fagleg reynsla sem forveri úr hópi djákna hefur byggt upp. Djákni sem er nýkominn til starfa án sterkra tengsla við samstarfsfólk sitt eða fyrri innri pekkingu á kirkjulegri pjónustu sem hann getur byggt starf sitt á stendur að einhverju leyti að í lausu lofti. Nýsköpun á sér einfaldlega ekki stað í tómarúmi og pegar djáknar hafa ekki traustan grunn til að byggja starf sitt á getur verkefnið reynst peim flókið og jafnvel illmögulegt.

\section{Horft til framtíðar}

- Degar unnið verður að mótun framtíðarsýnar í kirkjunni er gífurlega mikilvægt að kirkjan hafi á einum stað upplýsingar um heildarstarfsemi sína. Mikilvægt er að á Biskupstofu sé til gagnagrunnur með upplýsingum um störf og starfshlutföll, alls starfsfólks kirkjunnar, ekki aðeins djákna og presta.

- Brýnt er að endurmóta tilsjónarhlutverk prófasts með sérstöku tilliti til djákna sem starfa við fjölbreytta sérpjónustu í félagasamtökum og hjá stofnunum.

- Í tengslum við gagnagrunnskerfi sem héldi utan um upplýsingar um starfsfólk í pjónustu kirkjunnar, par með talið djákna, parf að útbúa ferla svo að djáknar og annað starfsfólk kirkjunnar geti á einfaldan hátt sinnt upplýsingagjöf til biskups og Biskupsstofu.

- Starfsreglum kirkjunnar er ekki nægilega vel fylgt við auglýsingar á djáknastörfum. Meginástæða pess er að djáknastörf í kirkjunni eru mjög fá og í flestum tilfellum er um nýsköpunarverkefni að ræða sem viðkomandi djákni/djáknakandídat leiðir og/eða hefur próað. Af peim sökum er engum greiði gerður með að krefjast pess að störfin séu auglýst, enda eru pau flest mótuð af peim einstaklingi sem kemur til með að gegna peim.

- Djáknar og djáknakandídatar purfa að hafa fastmótaða ferla sem pau geta notast við pegar pau hanna og móta nýtt starf, par sem biskup metur hvort um sé að ræða djáknastarf. Slíkur ferill myndi endurspegla raunverulega mótun djáknapjónustunnar á Íslandi mun betur en núverandi starfsreglur.

- Í ljósi pess að djáknar munu flest móta og bróa starf sitt sjálf er mikilvægt, sér í lagi í grunnnáminu (BA-náminu) að lögð sé mun sterkari og meiri áhersla á nýsköpun og safnaðaruppbyggingu en nú er gert. Вað hefur enda sýnt sig að BAnemar endast mun skemur í starfi en pau sem hafa annan bakgrunn hvað starfsreynslu og menntun varðar. 